\title{
MALAYSIA-SOUTH KOREA ECONOMIC RELATIONS: MAHATHIR MOHAMAD MADE THE DIFFERENCE
}

\author{
Song Miyoung \\ Sivachandralingam Sundara Raja
}

\begin{abstract}
The foreign policy of Malaysia during the first tenure of Dr. Mahathir reflected attempts at economic regionalism through active and assertive diplomacy. Mahathir's Look East Policy (LEP), importantly, was geared towards reinforcing Malaysia's relations with South Korea in terms of economic rather than political cooperation. Economic cooperation between Malaysia and South Korea materialized to a great extent when both countries undertook mega projects like the PETRONAS Twins Towers and Penang Bridge construction and elevated operations of Samsung Electronics. As far as Malaysia is concerned, it gained tremendous economic growth as a result of such bilateral economic collaborations with South Korea especially in the 1990s during the Mahathir era. This article examines the development of economic relations between Malaysia and South Korea during Dr. Mahathir's first tenure as the Malaysian Prime Minister with an emphasis on the ways in which he made significant strides in furthering their bilateral relations. Using both qualitative and quantitative data collected in the form of primary and secondary sources from the Arkib Negara Malaysia, Ministry of Foreign Affair Malaysia, Export Import Bank Korea, Malaysian Investment Development Authority (MIDA), and the researcher's interview with Mahathir Mohamad himself, the article elaborates three key areas - Mahathir's LEP in relation to South Korea and Malaysia-South Korea relations in terms of bilateral trade and investment.
\end{abstract}

\section{Introduction}

International relations are fundamentally the functioning of various types of diplomatic relations. One of the major significances in diplomatic approach is in to promote trade and investment under the framework of bilateral or multilateral agreements. ${ }^{1}$ Economic relations of states, especially those categorized as economically developing, are necessarily guided by changes in the international system and policies as well as connections established in relation to regional geo-economic superpower(s). Malaysia-South Korea economic relation is one which evolved as a result of changes in the international system. Mauzy and Milne observes that due to the geographic, demographic, economic and strategic importance of Malaysia, many countries started establishing relations with it, encouraging foreign investment flow and stronger trade vigorousity. ${ }^{2}$

Diplomatic relations between Malaysia and South Korea commenced on 23 February $1960 .{ }^{3}$ South Korea was at that time engaged in an extensive geo-political competition with North Korea for international recognition and legitimacy. Southeast Asia was among the important arenas of this competition. ${ }^{4}$ Similarly, Malaysia sought to establish itself as a legitimate democratic country having just been liberated from the yoke of colonialism in 1957. Having engaged in militaristic conflict against a communist insurgency, Malaysia favored diplomatic relations with South Korea as opposed to that with the communist North Korea. As can be seen from the officials' visits of both the countries in Table 1, the first twenty years of diplomatic relationship between Malaysia and South Korea were characterized by ideological and political cooperation. 
Table 1: Higher Level visits by South Korean to Malaysia

\begin{tabular}{|l|l|}
\hline Month/Year & \\
\hline July 1961 & Goodwill delegation led by Ambassador to South Vietnam Du Shin Choi \\
\hline February 1961 & Presidential special envoy Kim Jong Pil \\
\hline December 1964 & Foreign Minister Lee Dong-Won \\
\hline January 1965 & Chairman of Foreign Affairs Committee of National Assembly Kim Dong-Hwan \\
\hline September 1965 & Prime Minister Chung II-Kwon \\
\hline February 1966 & President Park Chung Hee \\
\hline March 1972 & Foreign Minister Kim Yong-Sik \\
\hline March 1975 & Foreign Minister Kim Dong-jo \\
\hline March 1976 & Foreign Minster Park Tong-jin \\
\hline June 1981 & President Chun Doo-Hwan \\
\hline
\end{tabular}

Source: Researcher's personal collected data from Korean National Archives, Ministry of Information Office, Hongboguk, South Korea

Evidently, as seen in Figure 1, trade relations between both countries took off slowly in the initial years. ${ }^{6}$ South Korean exports to Malaysia in 1963 amounted to USD 775,000 and accounted for a mere 0.8 percent of its total exports of textile, agricultural, and marine products. Malaysia's exports to South Korea were valued at USD 478,000, comprising mostly raw materials such as timber, rubber, coconut, and tin. ${ }^{7}$ South Korea's foreign direct investment (FDI) in Southeast Asia began in 1969 when the Namband Development Co. entered Indonesia for a forestry development project. However, discouraged by the government's restrictive investment regulatory measures to cope with its current account deficit problem, it remained insignificant until the mid-1980s. ${ }^{8}$ This was reflected in its early bilateral trade agreement with Malaysia not leading to immediate significant changes. ${ }^{9}$ 
Figure 1: Malaysia-South Korea Bilateral Trade (USD thousands)

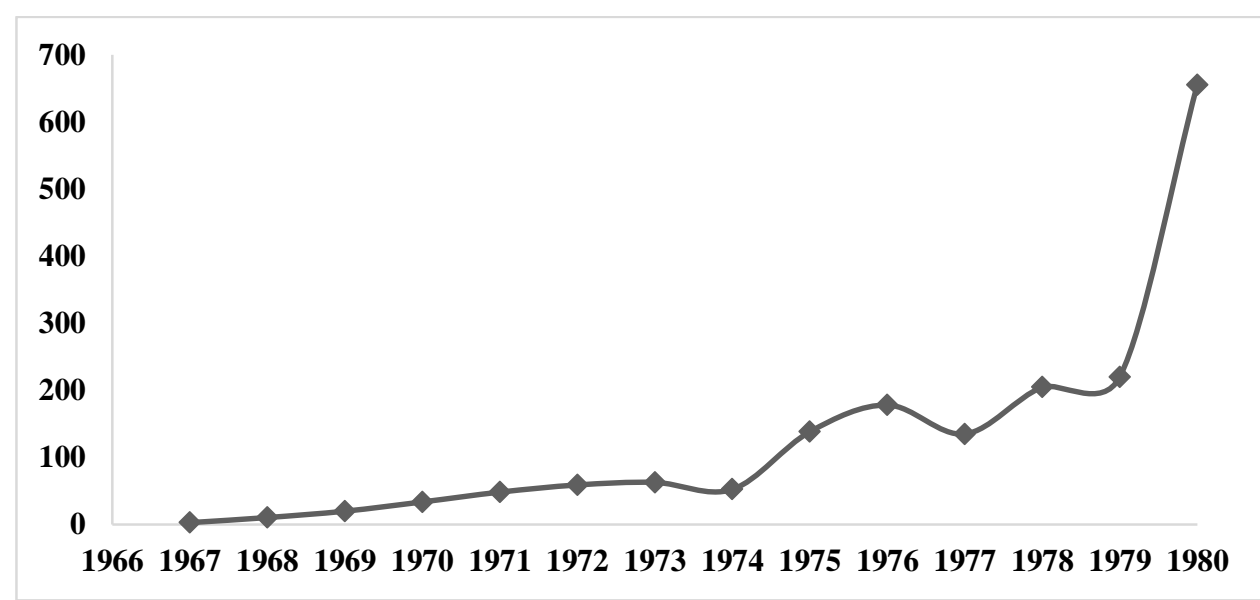

Source: Malaysian Investment Development Authority (MIDA), 1966-1980

This soon changed after Chun Doo-hwan took the helm as the new South Korean President after the demise of Park Chung-hee in 1980. Under Chun's administration, the country underwent several structural changes in economic and foreign policy to solve the problems of high unemployment rates and declining exports. He was keen to reduce the country's heavy dependence on traditional trading partners such as Japan and the U.S. and instead focused on developing complementary economic relationships. ${ }^{10}$ For this purpose, Southeast Asian countries were identified as the new strategic business partners having large accessible market, low labour cost and most importantly, abundant raw materials. Being a resource-poor nation, Korea had to import raw materials to support its ever-growing manufacturing industry such as textile, electronic, petrochemical, etc. ${ }^{11}$ Southeast Asian countries such as Malaysia, Thailand and Indonesia were able to meet not only the industrial needs of South Korea, but were also attractive destinations for the investors.

Subsequently, President Chun made a two-week ASEAN visit in July 1981. In Malaysia, his visit continued from June 29 to July 1 when leaders of both countries reviewed the state of their bilateral relations and agreed to continue mutual cooperation. ${ }^{12}$ Following this visit, South Korea-Malaysia economic relations witnessed a growth in bilateral trade and economic cooperation, regular consultative talks at official level, and the active participation of the South Korean private sector in Malaysia's economic and development projects particularly in the construction sector. Unlike the 1960s and 1970s, when ideological and political cooperation had dominated their bilateral agenda, the issue of economic cooperation replaced political agenda as the central theme of bilateral relations ever since the 1980s. For instance, President Chun offered the services of South Korean experts under the Saemoul Undong movement to cooperate and assist in developing rural and agricultural sector. ${ }^{13}$ This was followed by an agreement for avoidance of double taxation and to hold negotiation for an early conclusion on an investment guarantee agreement. ${ }^{14}$ This first visit of Chun paved the way for increased economic interactions between the two countries.

Economic relations between Malaysia and South Korea were bound to take place when both countries identified congenial economic interests. Malaysia, being an economically developing country, focused more on tangible economic benefits while South Korea began to promote its economic bilateral cooperation with Malaysia. Their diplomatic relations strengthened especially after the 1980s with the timely introduction of the Look East Policy at the time of fundamental shifts in the international environment and vital variations in the global economic system. This article identifies the roles played Dr. Mahathir within 
this context of the multidimensionality and complexity of Malaysia-South Korea economic cooperation.

\section{Mahathir's 'Look East policy' vis-à-vis South Korea}

Malaysia experienced a paradigm shift when Prime Minister Dr. Mahathir Mohamad came to power in the early 1980s. Impressed by the growth and economic development of East Asian countries particularly Japan and Korea, Dr. Mahathir was keen to have these countries as models for Malaysia's own development. Chun's visit to Malaysia in 1981 proved an important step for Dr. Mahathir to emulate and implement the work ethics of the East Asians in Malaysia. South Korea became a special focus of Dr. Mahathir in his Look East Policy (LEP).$^{15}$ The initiation of LEP, launched in 1981, catapulted Malaysia's relation with South Korea to a new level as the policy officially recognized the country (along with Japan and Taiwan) as a model of successful economy built upon East Asian work ethics and cultures. ${ }^{16}$ He urged Malaysians to commit themselves to learning and practising Japanese and Korean work ethics and told them to look East where people are hard-working, and to emulate the diligence in work, efficiency in management and trade relations and other aspects found in the East. ${ }^{17}$ In a speech in 1983 , he stated that:

There is no doubt in my mind that it is the Korean attitude towards work, their loyalty and discipline that have contributed to the economic miracle of the Republic of Korea ${ }^{18}$.

He further argued that Malaysia could learn from Japan and South Korea to develop their work skills and for improving productivity from technology transfer. As part of this policy, Mahathir introduced the 'Brain Child policy' based on the idea that work ethics and managerial skills of Japan and South Korea were transferable to Malaysia to increase its productivity and industrial growth. Various efforts were made to increase trade relations with South Korea and Japan. Malaysians were sent to Japan and South Korea for exposure and job training. Malaysia also began to provide government-funded scholarships for its students to study in South Korean universities. Many Malaysian government officials also underwent training in Korea. During his visit to South Korea in 1983, Dr. Mahathir remarked:

As you know we have introduced the "Look East Policy" for Malaysia, by which we learn from the experiences of the countries in East that have achieved success such as the Republic of Korea and Japan. I am convinced that with proper adaptation, taking into account the different circumstances in Malaysia, we could adopt and apply the methods and approaches that you have used so successfully in your economic and industrial development. ${ }^{19}$

LEP, which provided a mutually approachable bilateral atmosphere between both countries, emphasized the adoption of development model of South Korea and increased technology transfer and other linkages, subsequently contributing to the advancement of Malaysia-South Korea economic partnership. This is especially seen in the country's remarkable economic performance decades prior to the formulation of LEP. During the 1960s and 1970s, South Korea achieved remarkable economic development in spite of critical situations like natural resources, low national savings, a narrow domestic market, and the Korean War. In 1962, the first five-year plan was launched by South Korea and then expanded at average annual rates of $9.2 \%$ and $33.7 \%$ by $1979 .{ }^{20}$ During the 1970 s, some difficulties existed such as oil shocks, political turmoil and disastrous domestic agriculture harvest. Having said that, South Korea still managed to sustain its economic growth up to 
9.9\% between 1980 and 1991 (see Table 2). The country's higher-level performance in terms of major economic indicators was the economic benchmark that Dr. Mahathir's envisioned to achieve through his LEP (Table 2).

Table 2: Major Indicators of Growth for Malaysia and South Korea

\begin{tabular}{|l|c|c|}
\hline & Malaysia & South Korea \\
\hline Population (millions) & 18.2 & 43.3 \\
\hline Population Growth rate (\%) & 2.6 & 0.9 \\
\hline Area (km) & 329758 & 99237 \\
\hline Literacy & 78.5 & 96.0 \\
\hline GNP (US \$ billions) & 40.38 & 236.9 \\
\hline GNP per Capita (US\$) & 2320 & 5400 \\
\hline GDP Growth rate (1981-90) & 5.2 & 9.9 \\
\hline Sectoral Share of GDP (\%) & & 9.1 \\
\hline Agriculture & 18.6 & 0.5 \\
\hline Mining & 9.7 & 31.4 \\
\hline Manufacturing & 26.8 & 12.9 \\
\hline Construction & 3.6 & 46.1 \\
\hline Services & 38.9 & 71.9 \\
\hline Exports (US\$ billions) & 34.4 & 81.6 \\
\hline Imports (US\$ billions) & 36.4 & 6.5 \\
\hline Inflation Rate (\% change in CPI) & 3.3 & \\
\hline
\end{tabular}

Source: ADB, Asian Development Outlook 1991; The Economist Intelligence Unit, Country Report, 1991. Quoted from Lee Kyung Chan, "South Korea-Malaysia Relations: A Study of Political Economy of Interdependence", Department of Southeast Asian Studies, Master Thesis, University of Malaya, 1995, p. 227.

As such, Malaysia's foreign policy under the Dr. Mahathir was not merely a form of "continuity" that helped Malaysia to achieve its goals. ${ }^{21}$ Rather, it was significantly realigned when the Mahathir placed economic and trade at the forefront. His LEP represented his attempt at promoting economic regionalism through which Malaysia not only preserved its political relation with the 'East Asian Tigers' but also in essence established and diversified its economic relations with them. The end of Malayan Communist Party's (MCP) insurgency and the lessening of the Cold War 'bipolar tension' in the 1980s, when Mahathir began his first term as Prime Minister, led to a decrease in emphasis on political and military agenda in his national policy. These were evident changes that proved economic and social developments took precedent over security and defence in Malaysia under Dr. Mahathir's leadership.

Accordingly, Dr. Mahathir's foreign policy focused on international trade agreements, foreign investments and partnerships with non-traditional economic partners as well as South-South cooperation. A long-term anticipation through expanding economic cooperation in non-traditional regional markets was to reduce Malaysia's dependency on industrialized countries. At the same time when Malaysia adopted a lukewarm strategy towards the Commonwealth and Great Britain, its relationship with East Asia and Japan was on the other 
hand emphasized. In stating his rationale for gradually ending dependency relations with industrialized former colonial powers through South-South cooperation, Dr. Mahathir stated "nations in the South are poor but they form big market. These countries alone cannot affect the rich country`s attitude. It is important for these nations to show a united front.",22

\section{Malaysia-South Korea Trade Relations}

Under Dr. Mahathir, conscious efforts were taken to increase trade and investment with South Korea. In the award of contracts for major projects in Malaysia, preference was given to firms from Japan and South Korea. ${ }^{23}$ Through these cooperative projects, advanced technology and knowledge from South Korea and Japan were transferred and shared. To further enhance the ties between Malaysia and South Korea, Dr. Mahathir made an official visit to South Korea and met Chun in 1983. Chun was enticed with the LEP idea and was determined to give his full support to the policy. ${ }^{24}$ As a result, the volume of bilateral trade between both the countries exceeded one billion dollar in $1983 .{ }^{25}$

One of the major factors behind the success of Malaysia-South Korea bilateral economic relations was the recognition among both countries' leaders on the importance of an export-oriented economy. Major imports of South Korea were manufacturing materials due to lack of natural resources, therefore necessitating foreign exchange through exports of industrial output. The policy makers of South Korea were aware of their small domestic market to expand its modern industry and that its demands were to be found abroad. Thus, South Korea's economy was built more on export foundation. ${ }^{26}$

Similarly, in the development of Malaysia's economy, trade played major role and for an economic take-off export oriented strategy was implemented. In order to get supply of capital and intermediate goods as well as increasing markets for its products, Malaysia not only welcomed foreign investment and increased trade but also expanded economic interaction with other developing countries in the Pacific region. Beginning from the 1970s, foreign trade of Malaysia increased due to growth of agricultural and industrial production. This saw a major shift under the leadership of Dr. Mahathir. In 1980, foreign trade of Malaysia was 10 times greater than it was in the 1970s and it amounted to US\$ 34,466 million. ${ }^{27}$

Malaysia-South Korea bilateral trade relations further strengthened when their essentially export-oriented economy was reinforced by a relatively high import propensity between each other. During the period 1970-90, although the average propensity rate of South Korean imports from Malaysia was somewhat uneven, the country's propensity to import Malaysian products exceeded those of other countries. This indicates that South Korea imported more goods from Malaysia than any other nations. South Korean propensity to import Malaysian products is shown in Table 3.

Secondly, although the average propensities of South Korea surpassed other nations, its absolute level remained under $1 \% .{ }^{28}$ This fact explains that South Korea expended less than $1 \%$ of its GNP to import manufacturing and primary goods from Malaysia. Thirdly, both marginal and average propensities of South Korea to import goods from Malaysia rose over the time. With increasing GNP per capita, South Korea became major targets of entrepreneurs of Malaysia not only for primary commodities but for manufactured products as well. ${ }^{29}$

Table 3: South Korea: Propensity to Import Malaysian Products, 1970-1989 


\begin{tabular}{|c|c|c|}
\hline Year & Average propensity & Marginal Propensity \\
\hline $1970 \mathrm{~s}$ & 0.7182 & 0.5931 \\
\hline $1980 \mathrm{~s}$ & 0.9388 & 2.555 \\
\hline $1990 \mathrm{~s}$ & 0.9120 & 1.5254 \\
\hline
\end{tabular}

Sources: International Monetary Fund, Direction of Trade Annual 1969-75; International Monetary Fund, Direction of Trade Statistics yearbook 1979, 1984, 1987, 1992; International Monetary Fund, International Financial Statistics Yearbook 1992. Quoted from Lee Kyung Chan, "South KoreaMalaysia Relations: A Study of Political Economy of Interdependence”, p. 70.

Similarly, Malaysian propensity to import South Korean products (Table 4) shows interesting features. Firstly, the average propensity for Malaysia to import from South Korea implies that Malaysia was spending more on buying manufactured products from South Korea. Imports from South Korea were mostly industrial goods replacing imports from other sources. The average import propensity of both countries, therefore, shows that the mutual cooperation between both countries was in such a way it was mostly harmonious.

Table 4: Malaysia: Propensity to Import South Korean Products, 1970-1989

\begin{tabular}{|c|c|c|}
\hline Year & Average propensity & Marginal Propensity \\
\hline 1970 's & 0.2196 & 0.3338 \\
\hline 1980 's & 0.8400 & 0.6460 \\
\hline 1990 's & 1.1192 & 2.7076 \\
\hline
\end{tabular}

Source: Lee Kyung Chan, "South Korea-Malaysia Relations: A Study of Political Economy of Interdependence", p. 217. Note for Table 3 and 4: Data in US\$ millions is converted from GDP in Malaysia Ringgit using average annual exchange rate. 
Figure 2: Malaysia-South Korea Bilateral Trade (X)

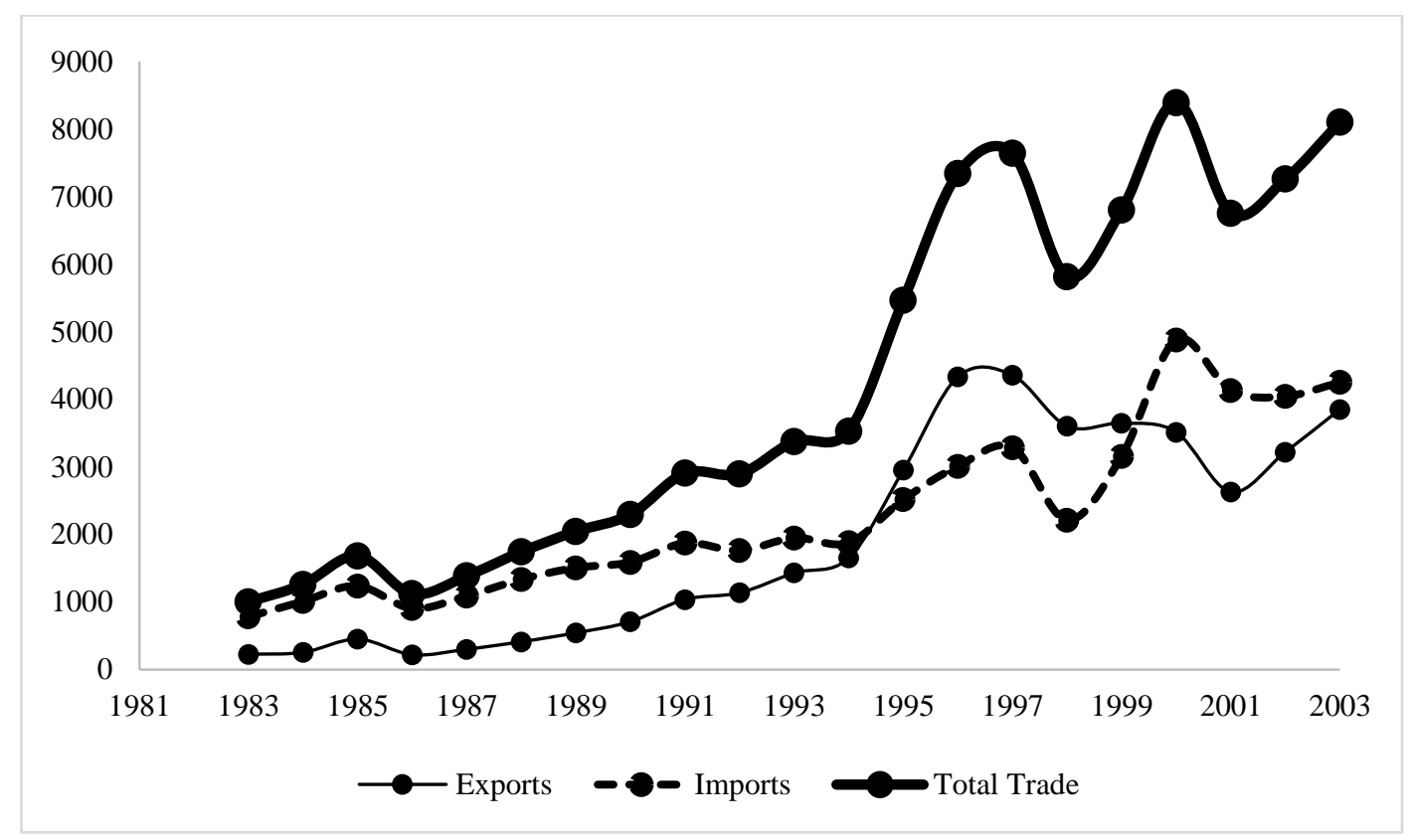

Source: Malaysian Investment Development Authority (MIDA), 1981-2003

During the period of Chun Doo-hwan (1980-1988), Korean-Malaysian cooperation was bolstered through a number of bilateral agreements, including the Avoidance of Double Taxation Agreement (1982), the visa Abolition Agreement in 1983, the Technology and Science Co-operation Agreement in 1985, and the Investment Guarantee Agreement in 1988. ${ }^{30}$ Figure 2 shows remarkable improvement in bilateral trade between both countries after the 1980s. The percentage of Malaysian trade with South Korea also increased smoothly starting during the period of Chun Doo-hwan and Dr. Mahathir, as shown in Figure 3.

Figure 3: Malaysian Percentage of Trade with South Korea

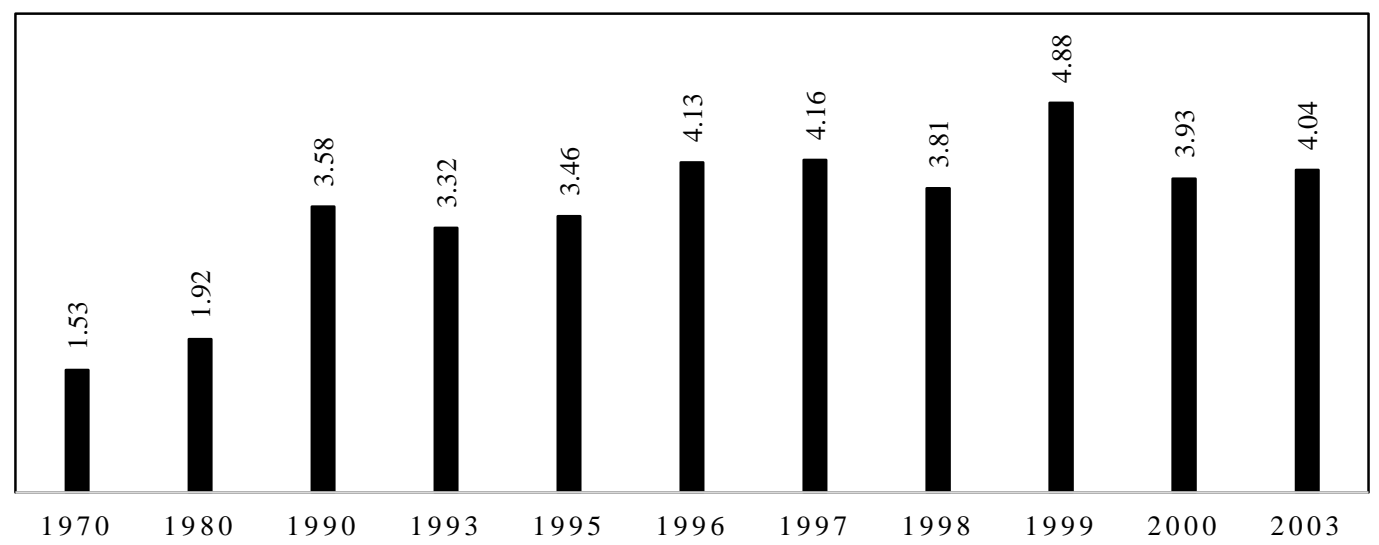

Source: Malaysian Investment Development Authority (MIDA),1970-2003

It must be added that new developments in South Korea-Malaysia relations were also mainly due to the administration in both countries identifying external trade dependency as a major constraint to economic growth. The external dependency of these two countries is shown in Table 5, which enlists the relative portion of trade volume to GDP of different economies. South Koreas` dependency ratio was high but the dependency ratio of Malaysia 
was much greater. High degree of economic openness by Malaysia emphasized agricultural development and mining for export purposes. On the other hand, South Korea had to import raw material for manufacturing of export products due to poor natural resource endowment. Both Malaysia's and South Korea's external orientation brought about the internationalization of their economies. Due to high trade with regional economies, it was perceived by Malaysia and South Korea that economic interaction in Asia-Pacific region was important for their continuous economic growth.

Table 5: Economic Openness of Selected Countries

\begin{tabular}{|c|c|c|c|c|}
\hline Country & GDP (US millions) & Trade Volume & Trade Volume & I+E/ GDP \\
\hline U.S.A & 5156440 & 491512 & 346948 & 152403 \\
\hline U.K & 717870 & 197714 & 275040 & .49 \\
\hline Japan & 2818520 & 207356 & 28731 & 16 \\
\hline Hong Kong & 52540 & 72154 & 62283 & .17 \\
\hline South Korea & 211880 & 61347 & 25053 & 1.27 \\
\hline Malaysia & 37480 & 22496 & 21773 & .41 \\
\hline Indonesia & 93970 & 16360 & 7747 & .42 \\
\hline Philippines & 44350 & 10732 & 44600 & 3.32 \\
\hline Singapore & 28360 & 49605 & 20059 & .66 \\
\hline Thailand & 69680 & 25768 & & .92 \\
\hline
\end{tabular}

Source: The World Bank Development Report 1991. Quoted from Lee Kyng Chan, p. 230.

Chun Doo-Hwan's inclination towards ASEAN countries and Mahathir's LEP shifted the direction of trade for both countries. South Korea, for its part, was keen to reduce its heavy reliance on traditional trading partners such as Japan and the United States. South Korea's movement along this direction is clearly seen when its increased trade with Malaysia corresponded with a decrease with the United States and Japan after the 1980s (Figure 4). On the other hand, Malaysia's trade direction also shows a similar shift, as seen in Figure 5.

Figure 4: South Korean Trade Direction

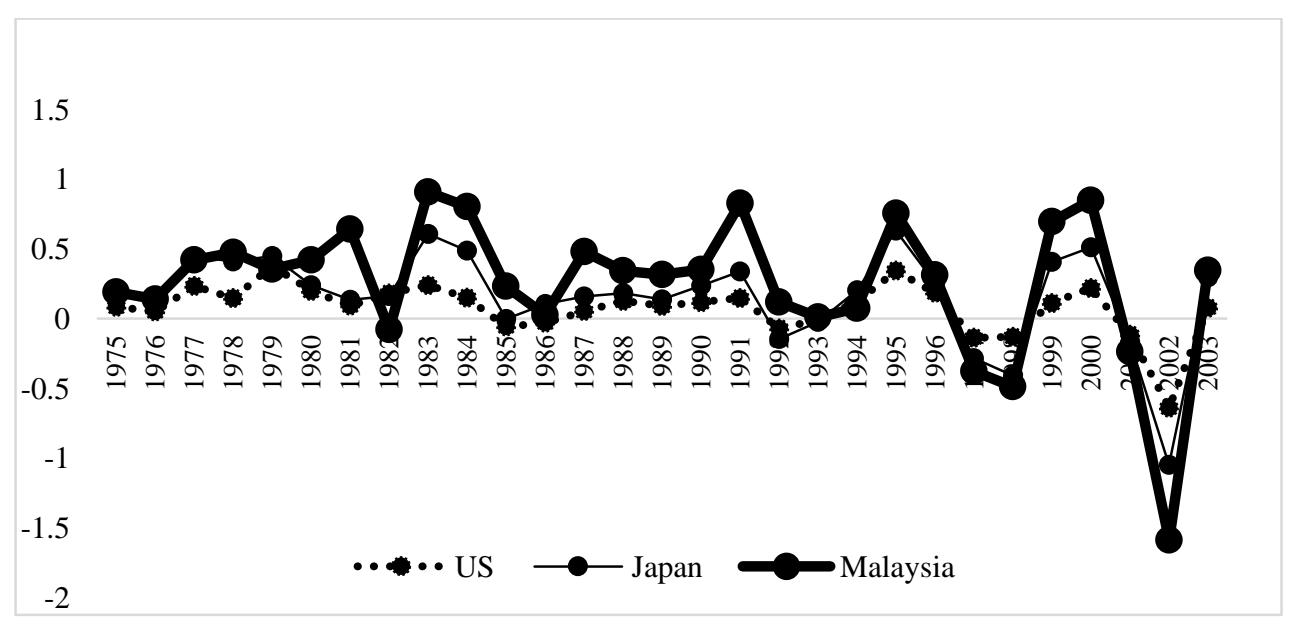

Source: Direction of Trade Statistics, 1975-2003, International Monetary Fund (IMF) 
Figure 5: Malaysian Trade Direction

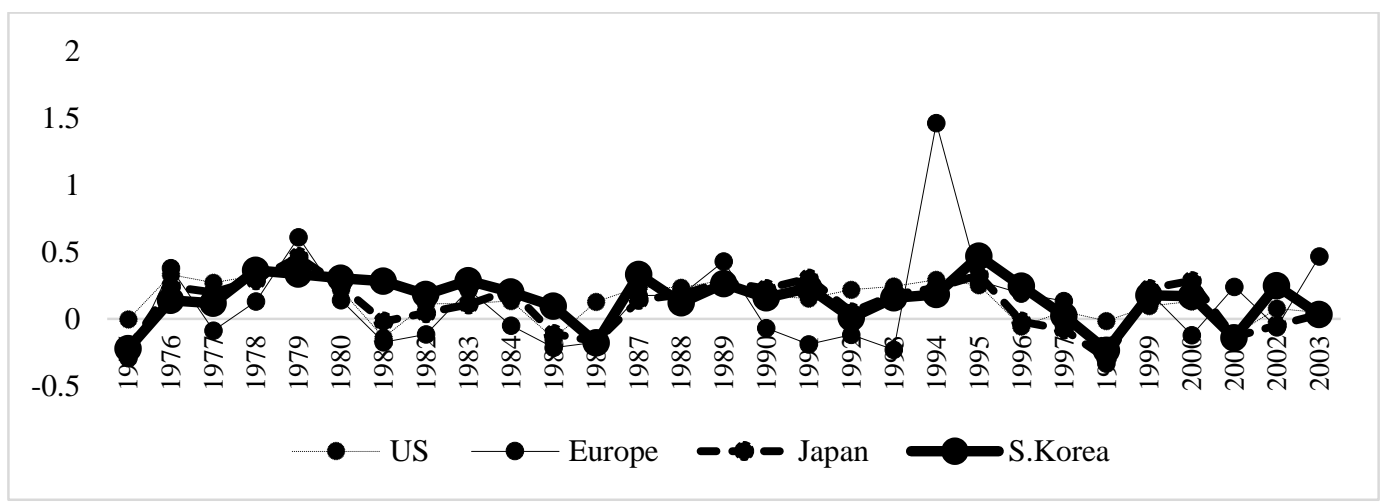

Source: Direction of Trade Statistics, 1975-2003, International Monetary Fund (IMF)

In June 1987, Chun named Roh as the presidential candidate of the ruling Democratic Justice Party. Subsequently, he was elected as the president on December 16, 1987 and was inaugurated as President on February 25, 1988. ${ }^{31}$ The general philosophy of the Chun presidency and, even more overtly, the succeeding Roh presidency, was more or less similar. ${ }^{32}$ During the former's presidency, the average growth in bilateral trade between Malaysia and South Korea remained at $18.2 \%$, which is comparable with the average trade growth of $17.4 \%$ of Chun's period. ${ }^{33}$ Ministers from different ministries of both countries visited each other's country to cooperate in different fields. From Malaysia, the Minister of Agriculture (February 1988), Minister of Commerce and Industry (April 1988), and Minister of Primary Industry and Trade (1991) paid official visits to South Korea for the development of the sector each ministry represented. In April 1982, the Ministry of Agriculture Malaysia sought expert assistance from South Korea in the field of aquaculture development. ${ }^{34}$ The official visit by the Minister of Agriculture in 1988 suggests both countries followed the policies already set during the Chun period. Similarly from South Korea, under Roh's administration, the visits by its ministers of Commerce and Trade and Energy and Resources in 1989, 1990, and 1991, indicate that South Korea continued seeking primary energy resources from Malaysia.

During his official visit to South Korea on October 12, 1990, Mahathir in his speech highlighted the progress in bilateral trade by stating:

Both Korea and Malaysia have made great strides in the area of bilateral trade. The Republic of Korea is today Malaysia's sixth largest Asian trading partner and our fourth largest export market. Total trade last year stood at almost $\mathrm{M} \$ 5$ billion. I am happy to note that Malaysia has emerged as a major supplier of commodities for Korea's industries. Malaysia currently accounts for 74\% of Korea's rubber and latex requirements, $95 \%$ of Korea's palm oil imports, $42 \%$ of Korea's sawn log requirements and nearly $15 \%$ of its crude oil needs. Korea can continue to depend on Malaysia as a reliable and competitive source of these important commodities. At the same time, Malaysia's exports of manufactured goods to Korea have also increased and now account for more than $15 \%$ of total exports. ${ }^{35}$

Figure 6 shows the top five products by sizes that were traded between South Korea and Malaysia. From South Korean, top exports include capital goods followed by machinery 
and electronics, intermediate metal products and consumer goods. ${ }^{36}$ On the other hand, South Korean imports from Malaysia consisted of fuels, raw materials, wood, and plastic. ${ }^{37}$ However, there was a decline in trade in 1997 and 1998 due to the Asian Financial Crisis.

Figure 6: Trade by Product

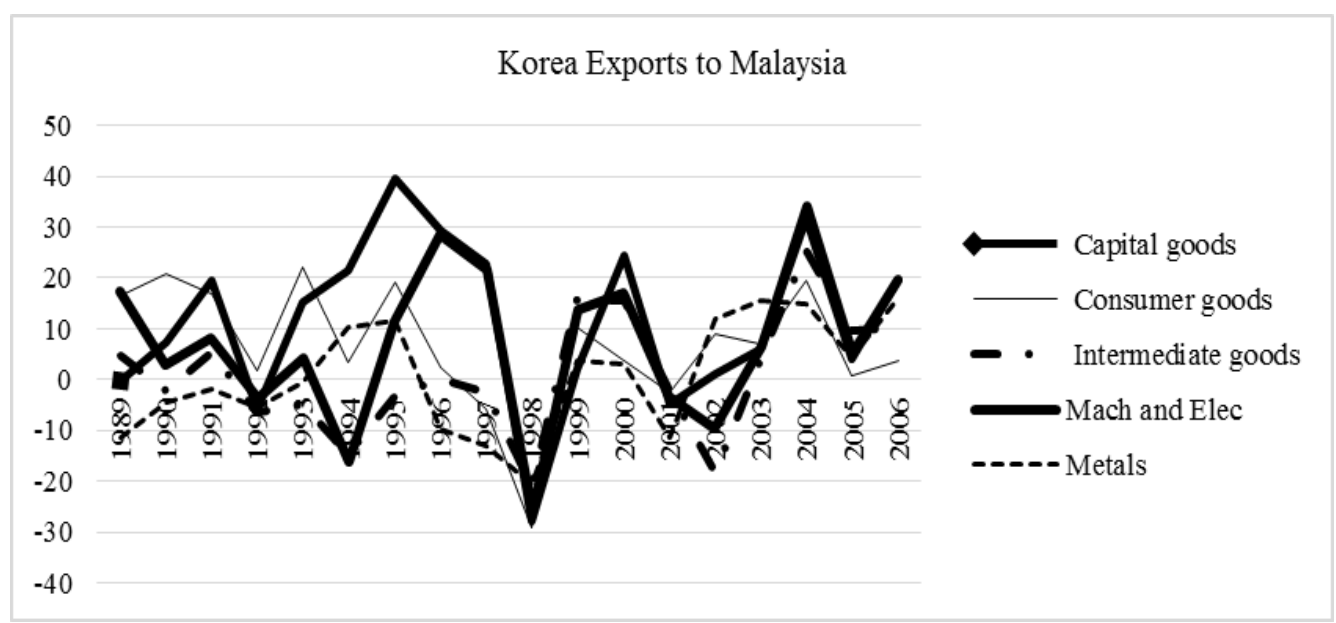

Source: World Integrated Trade Solution (WITS), 1988-2008

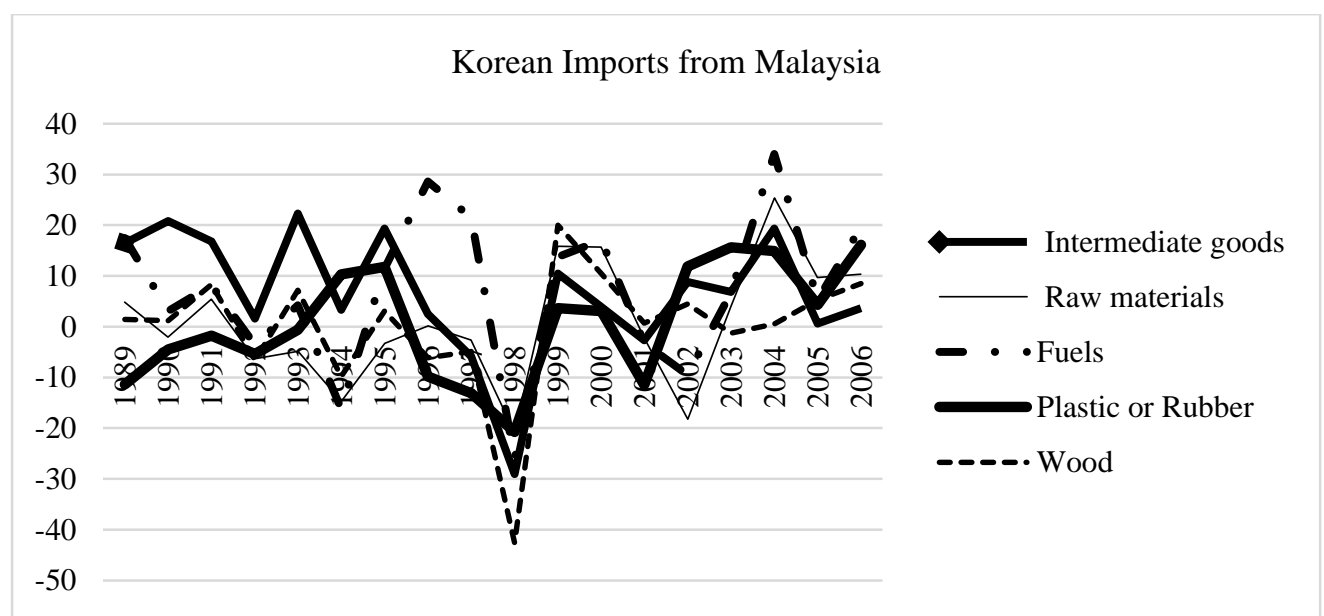

Source: World Integrated Trade Solution (WITS), 1988-2008

At the end of Roh Tae Woo's tenure in 1992, Malaysia was South Korea's largest source of natural rubber $(27.7 \%)$ as well as wood, lumber and cork (35.7\%). Imports of mineral fuels and crude petroleum from Malaysia accounted for $4 \%$ and $5.9 \%$ respectively. ${ }^{38}$ Overall, primary evidence suggests that Roh Tae Woo inherited the economic legacy of Chun Doo-Hwan to maintain strong economic ties with ASEAN countries particularly Malaysia. After Roh Tae Woo' presidency, South Korea had the first democratically elected president, Kim Young-sam (1993-1998), followed by Kim Dae-Jung (1998-2003). The economic relationship of South Korea with Malaysia remained unchanged during their period of presidency. For instance, from 1994 to 1998, Malaysian exports to the South Korea showed a gradual increase with a slight contraction in 1998 (-7.5\%). A significant jump in exports was recorded in 1999 and 2000 resulting in a two-fold increase against exports in 1998. The 
export value in 2000 was the highest recorded during the last decade. ${ }^{39}$ Since then, exports appeared cyclical, fell slightly in 2001, up in 2002 and contracted again in 2003. Increasing sourcing from South Korean factories based in China was the factor that led to the contraction in exports. ${ }^{40}$ Korean imports by products exhibited similar pattern with that of the previous governments of Chun Doo-Hwan and Roh Tae Woo. For instance, the top five exports to South Korea in 2003 were electrical products, fuel, crude petroleum, chemicals and wood products. This collectively contributed 76.7 percent of total exports to South Korea in 2003, an increase of 50.1 percent in $1994 .{ }^{41}$

What these primary statistics add to our understanding is that bilateral trade between Malaysia and South Korea witnessed a paradigm shift in the 1980s when Chun visited Malaysia and the subsequent imitation of Dr. Mahathir's LEP. From then onwards, MalaysiaSouth Korea economic relations only got stronger with succeeding administrations of both countries. This implies that the initial visions of Mahathir and Chun set forth the course for fruitful bilateral economic relations between both countries: as it is obvious that trading relations increased under Dr. Mahathir's leadership. While there was an increase in trade volume between both countries up to 1979 , it should be noted that trade volume quadrupled for the first time between 1979 and 1989 and increased rapidly ever since 1990 (Table 6). Malaysia stood at third place in supplying materials to South Korea exporting goods worth US\$1,586. On the other hand, Malaysia was South Korea's seventh largest trading country, and particularly for exports it was the fourth largest.

Table 6: South Korea's Trade with Malaysia, 1970-2003 (Millions US\$)

\begin{tabular}{|l|c|c|c|c|c|}
\hline Year & Export & Import & Balance & Total & Balance/Total \\
\hline 1970 & 1.3 & 57.8 & -56.6 & 59.1 & 0.96 \\
\hline 1971 & 1.3 & 61.6 & -60.3 & 62.9 & 0.96 \\
\hline 1972 & 3.5 & 49 & -45.5 & 52.5 & 0.87 \\
\hline 1973 & 6 & 132.4 & -126.4 & 138.4 & 0.91 \\
\hline 1974 & 18 & 161.1 & -143.1 & 179.1 & 0.8 \\
\hline 1975 & 12.3 & 122.8 & -110.5 & 135.1 & 0.82 \\
\hline 1976 & 18 & 186.6 & -168.6 & 204.6 & 0.82 \\
\hline 1977 & 24 & 197 & -173 & 221 & 0.78 \\
\hline 1978 & 47.5 & 227.9 & -180.4 & 275.4 & 0.66 \\
\hline 1979 & 85.8 & 383.2 & -297.4 & 469 & 0.63 \\
\hline 1980 & 183.9 & 471.6 & -287.7 & 655.5 & 0.44 \\
\hline 1981 & 162.7 & 643.2 & -480.5 & 805.9 & 0.6 \\
\hline 1982 & 233.5 & 609.6 & -376.1 & 843.1 & 0.45 \\
\hline 1983 & 224.7 & 777.3 & -552.6 & 1002 & 0.55 \\
\hline 1984 & 253.2 & 1005.3 & -752.1 & 1258.5 & 0.6 \\
\hline 1985 & 449.6 & 1234.3 & -784.7 & 1683.9 & 0.47 \\
\hline 1986 & 218.8 & 901.7 & -682.9 & 1120.5 & 0.61 \\
\hline 1987 & 299.7 & 1086.3 & -786.6 & 1386 & 0.57 \\
\hline 1988 & 410.6 & 1331.4 & -920.8 & 1742 & 0.53 \\
\hline 1989 & 542.8 & 1503.3 & -960.5 & 2046.1 & 0.47 \\
\hline 1990 & 708.4 & 1586 & -877.6 & 2294.4 & 0.38 \\
\hline 1991 & 1037.2 & 1869 & -831.8 & 2906.2 & 0.29 \\
\hline 1992 & 1135.9 & 1758.2 & -622.3 & 2894.1 & 0.22 \\
\hline 1993 & 1430 & 1946.5 & -516.5 & 3376.5 & 0.15 \\
\hline 1994 & 1651.6 & 1875.9 & -224.2 & 3527.6 & -0.06 \\
\hline
\end{tabular}




\begin{tabular}{|l|c|c|c|c|c|}
\hline 1995 & 2950.8 & 2515.1 & 435.6 & 5466 & 0.079 \\
\hline 1996 & 4333 & 3006.5 & 1326.5 & 7339.5 & 0.18 \\
\hline 1997 & 4356.2 & 3282.6 & 1073.6 & 7638.9 & 0.14 \\
\hline 1998 & 3602 & 2210.5 & 1391.5 & 5812.5 & 0.23 \\
\hline 1999 & 3647.4 & 3155.3 & 492.16 & 6802.7 & 0.072 \\
\hline 2000 & 3514.6 & 4877.9 & -1363.2 & 8392.6 & -0.16 \\
\hline 2001 & 2628 & 4125.9 & -1497.9 & 6754 & -0.22 \\
\hline 2002 & 3218.3 & 4041.4 & -823.1 & 7259.7 & -0.11 \\
\hline 2003 & 3851.7 & 4249.1 & -397.3 & 8100.8 & -0.04 \\
\hline
\end{tabular}

Source: Foreign Trade Association of Korea, The Trend of Foreign trade, various issues, 1970-2003

Table 6 indicates the following facts (1) the absolute trade volume increased continuously; (2) the trade trend between the two nations affected economic growth; (3) trade volume in the 1980s was comparatively higher compared to the 1970s; and (4) the period 1990-2003 shows the highest growth between the two countries in terms of trade volume; (5) the growth rate of trade volume exceeded export growth. It should be noted that it was during the period of the implementation of Mahathir's LEP that a major increase in trade with South Korea took place.

A key characteristic of the Malaysia-South Korea trade relations during Dr. Mahathir's period is that their economic cooperation was mostly based on manufactured goods. In any case, the share of crude oil in their trade had already been decreasing from 96\%-86.8\% during 1970-1980 when, on the other hand, the proportion of industrial goods from Malaysia increased from 4\%-20\%. It was therefore only natural that the emerging manufacturing industries in Malaysia under Mahathir would have further contributed to even more increase in Malaysia's export of manufactured goods to South Korea (Table 7). Furthermore, the manufacturing economy of Malaysia was becoming more and more specialized due to increasing division of labour, which contributed to the total output and trade between both countries.

\section{Malaysia-South Korea Investment Relations}

Malaysia-South Korea economic relation is not only limited to trade, but also manifested in the investment sector. Surprisingly, until the beginning of the Dr. Mahathir's administration, there was no official South Korean investment in Malaysia. The first South Korean investment was made in 1982, when Dr. Mahathir announced the Look East Policy. It was worth about US\$ 100,000. As can be seen in Table 6, the South Korean's trade with Malaysia was relatively low between 1980 and 1985. This could be due to the international recession in the period 1980-1982. Moreover, this was the nascent phase of Dr. Mahathir's administration when he was still in the process of redefining and shaping the new role of the state. Also, the Look East Policy (LEP) was in its initial phase of implementation. During my personal interview with Tun Mahathir on $29^{\text {th }}$ August 2017, when he was asked about the state of South Korean investment in Malaysia, he expressed that:

Initially South Korean came here as contractor and developed Penang Bridge. So, initially, the South Korean investment remained small and started to grow with the investment of large companies such as Hyundai and Samsung. We have always welcome South Korean firms to invest in Malaysia and will continue to work to make it 
easier for Korean companies to invest in our projects and to conduct business in our nation. ${ }^{42}$

In South Korea, Chun Doo-Hwan was also in the process of controlling domestic problems such as inflation control and economic restructuring. ${ }^{43}$ However, South Korean investment grew from 1987 onwards. ${ }^{44}$ During this period, the South Korean economy became more stable, with the average growth rate during the Chun Administration (1981-1987) was 8.7 percent and the national GDP reached $\$ 100$ billion. Considering its growth rate in 1980 was at a dismal -1.5 percent, the new policies to deal with economic problems worked effectively. 
Table 7: Malaysia`s Exports to South Korea, During Mahathir Era, 1990-2003

\begin{tabular}{|c|c|c|c|c|c|c|c|c|c|c|c|}
\hline Years & Food & $\begin{array}{l}\text { Beverage } \\
\& \\
\text { Tobacco }\end{array}$ & $\begin{array}{l}\text { Crude } \\
\text { Material }\end{array}$ & $\begin{array}{l}\text { Minerals, } \\
\text { Fuels, } \\
\text { Lubricants. } \\
\text { Etc. }\end{array}$ & $\begin{array}{l}\text { Animal \& } \\
\text { Vegetable } \\
\text { Oil }\end{array}$ & Chemical & $\begin{array}{l}\text { Manufactured } \\
\text { Goods }\end{array}$ & $\begin{array}{l}\text { Machinery \& } \\
\text { Transports }\end{array}$ & $\begin{array}{l}\text { Misc. } \\
\text { Manufacture } \\
\text { Articles }\end{array}$ & $\begin{array}{l}\text { Misc. } \\
\text { Transactions }\end{array}$ & $\begin{array}{l}\text { Total Exports } \\
\text { (Millions } \\
\text { US\$) }\end{array}$ \\
\hline 1981 & 1134.5 & 29.8 & 7716.2 & 7144.6 & 3361.2 & 191.9 & 3281.3 & 2007.6 & 698.7 & 214.5 & 25781.2 \\
\hline 1982 & 1152.5 & 22.1 & 7583.2 & 7980.9 & 3255.8 & 235.8 & 2625.9 & 4335 & 753.8 & 163.2 & 28108.2 \\
\hline 1983 & 1272.9 & 28.2 & 8261.7 & 9300.5 & 3829.2 & 293.9 & 3035.1 & 5652.5 & 902.3 & 194.9 & 32771.2 \\
\hline 1984 & 1479.8 & 28.2 & 8121.2 & 11435.4 & 5868.2 & 426.7 & 2554.7 & 7322.9 & 1196.1 & 213.7 & 38646.9 \\
\hline 1985 & 1659.8 & 25.5 & 7268.4 & 12249.8 & 4845.6 & 441.1 & 3101.1 & 7155.8 & 1369.4 & 210.6 & 38327.3 \\
\hline 1986 & 1969.8 & 37.1 & 7883.8 & 8060 & 3609.6 & 600.5 & 2596.4 & 8995.8 & 1806.6 & 241.7 & 35801 \\
\hline 1987 & 2458.2 & 57.4 & 10583.4 & 8997.4 & 4167.6 & 736.3 & 3709.5 & 11700.7 & 2618.5 & 196.1 & 45224.9 \\
\hline 1988 & 2851.4 & 83.1 & 12418 & 8731.3 & 5762.6 & 1220.5 & 4487.8 & 15665.7 & 3829.5 & 210.1 & 55260 \\
\hline 1989 & 3128.9 & 80.2 & 12656.9 & 11023.6 & 6197.4 & 1234.2 & 5712.2 & 21982.9 & 5606.7 & 201.5 & 67824.5 \\
\hline 1990 & 3453.2 & 95.4 & 11480.2 & 14594.9 & 5679.7 & 1304 & 6329.3 & 28429.8 & 7955.5 & 324.3 & 79646.4 \\
\hline 1991 & 3651.6 & 169.2 & 11139.9 & 14658.7 & 6226.8 & 1666.7 & 7360 & 38865.6 & 10319.8 & 438.5 & 94496.6 \\
\hline 1992 & 3762.3 & 192.2 & 11080.5 & 13418 & 6874.7 & 2123 & 8830.8 & 45410.8 & 11504.5 & 459.9 & 103656.7 \\
\hline 1993 & 3975.2 & 184.7 & 10983.7 & 12470.9 & 7242.1 & 2639.2 & 11600.1 & 58796.8 & 12523.7 & 821 & 121237.5 \\
\hline 1994 & 4478.9 & 211.2 & 11522.8 & 11339.4 & 10485 & 4082.7 & 13905.7 & 82199.7 & 14609.3 & 1086.6 & 153921.2 \\
\hline 1995 & 4515.8 & 397.7 & 11991.8 & 12932.3 & 12634 & 5629.1 & 16339.9 & 101995.1 & 16131.6 & 2419.3 & 184986.5 \\
\hline 1996 & 4722.8 & 577 & 10759.4 & 15884.8 & 11726.8 & 6255.8 & 18289.9 & 108929.9 & 17713.7 & 2166 & 197026.1 \\
\hline 1997 & 5304.9 & 746.8 & 10102.1 & 17943.9 & 13000 & 7878 & 19870.6 & 123984.1 & 19325.5 & 2734.6 & 220890.4 \\
\hline 1998 & 6193.6 & 924.9 & 9312.8 & 17661.6 & 21386.1 & 9961.9 & 23819.2 & 169701.7 & 24945.7 & 2655.6 & 286563.1 \\
\hline 1999 & 6229.3 & 1046.5 & 9910.4 & 22480 & 18280 & 10353 & 24242.8 & 200071.5 & 26188.4 & 2757.7 & 321559.5 \\
\hline 2000 & 6470.3 & 1214.9 & 10288.3 & 35902.5 & 12936.9 & 14277.8 & 25788 & 233378.9 & 29925.1 & 3087.6 & 373270.3 \\
\hline 2001 & 6581.3 & 1307.7 & 7564.8 & 32288.3 & 12342.5 & 14318.4 & 24114.5 & 202827.8 & 29171.4 & 3767.1 & 334283.8 \\
\hline 2002 & 7477 & 1294.6 & 8418.1 & 30645.3 & 17925.6 & 16669.5 & 24844.9 & 215292 & 30452.8 & 4410.2 & 357430 \\
\hline 2003 & 8424 & 1492.2 & 10152.9 & 40231.6 & 24226.2 & 20549.9 & 27918.5 & 226077.6 & 33637 & 5111.6 & 397884.4 \\
\hline
\end{tabular}

Sources: Department of Statistics, Malaysia, Malaysia Annual statistics of External trade, Export \& Re-Export, various issues; External Trade Statistics, 1970-2003 
Table 8: Malaysia-South Korea Investment (USD Thousands)

\begin{tabular}{|c|c|c|c|c|c|}
\hline Year & $\begin{array}{c}\text { Number of } \\
\text { Acceptance }\end{array}$ & $\begin{array}{c}\text { Number of } \\
\text { New Overseas } \\
\text { Enterprises }\end{array}$ & $\begin{array}{c}\text { Accepted } \\
\text { Amount }\end{array}$ & $\begin{array}{c}\text { Number of } \\
\text { Remittance }\end{array}$ & $\begin{array}{c}\text { Invested } \\
\text { Amount }\end{array}$ \\
\hline 1980 & 5 & 3 & 209 & 4 & 151 \\
\hline 1981 & 4 & 3 & 26,580 & 3 & 1,215 \\
\hline 1982 & 3 & 2 & 239 & 3 & 508 \\
\hline 1983 & 6 & 5 & 406 & 9 & 12,833 \\
\hline 1984 & 6 & 2 & 1,431 & 4 & 3,311 \\
\hline 1985 & 3 & 4 & 508 & 6 & 9,759 \\
\hline 1986 & 2 & 1 & 714 & 1 & 116 \\
\hline 1987 & 1 & 1 & 208 & 3 & 794 \\
\hline 1988 & 10 & 3 & 3,447 & 3 & 1,294 \\
\hline 1989 & 24 & 7 & 35,588 & 10 & 3,082 \\
\hline 1990 & 50 & 18 & 70,497 & 36 & 17,227 \\
\hline 1991 & 45 & 27 & 31,169 & 75 & 69,563 \\
\hline 1992 & 44 & 23 & 33,062 & 59 & 23,484 \\
\hline 1993 & 26 & 15 & 10,243 & 49 & 23,896 \\
\hline 1994 & 37 & 16 & 170,036 & 42 & 20,063 \\
\hline 1995 & 37 & 19 & 83,039 & 55 & 116,499 \\
\hline 1996 & 40 & 19 & 68,802 & 57 & 53,030 \\
\hline 1997 & 40 & 20 & 83,840 & 45 & 21,820 \\
\hline 1998 & 37 & 10 & 24,209 & 49 & 22,077 \\
\hline 1999 & 31 & 11 & 41,794 & 48 & 39,770 \\
\hline 2000 & 42 & 20 & 37,289 & 61 & 33,726 \\
\hline 2001 & 35 & 17 & 31,464 & 47 & 21,710 \\
\hline 2002 & 34 & 23 & 112,439 & 50 & 62,290 \\
\hline 2003 & 31 & 17 & 31,344 & 60 & 46,302 \\
\hline
\end{tabular}

Source: Export-Import Bank of Korea, 1980-2003

During Chun's period, HICOM and the Penang Bridge construction were the major investment opportunities for Malaysia and South Korea. ${ }^{45}$ This sat the tone for further investments between both countries. Soon after Roh Tae Woo became the President, coinciding with the second phases of Dr. Mahathir's administration, investment in Malaysia also increased. This period moreover represented a transitioning phase from the NEP and the Mahathir-led government was now geared to induce more private investment by introducing the concept of Malaysia Incorporated (adopted from the Japanese model) and privatization. ${ }^{46}$ This change in investment trend could principally be attributed to the Mahathir administration's liberal foreign investment policies and the country's reputable economic infrastructure facilities. The appreciation of the Korean currency, the relaxation of foreign exchange controls by the South Korean Government in early 1989, and the escalating labour cost in South Korea, all contributed to an increased flow of South Korean investments into Malaysia. ${ }^{47}$ Among the ASEAN countries, Indonesia was at the top position in terms of investment volume of South Korea followed by 
Malaysia and the Philippines. In 1987, only 0.2\% of South Korean capital was absorbed by Malaysia, this share increased to 0.5\% - 1.8\% during the Mahathir period from 1989 to 1990; in 1991, investment share of Korea increased to 6.2\% (Table 9). For instance, when Chun DooHwan was the President, the total number approved Korean projects in Malaysia were 29. This increased to 174 during Roh Tae Woo's period (1988-1992).

Table 9: South Korea`s Outward FDI by region

\begin{tabular}{|l|c|c|c|}
\hline Region & $\mathbf{1 9 7 0 s}$ & $\mathbf{1 9 8 0}$ & $\mathbf{1 9 9 0 \mathbf { s }}$ \\
\hline ASEAN & 0.8 & 30.9 & 29.0 \\
\hline Indonesia & 0.8 & 30.5 & 15.1 \\
\hline Malaysia & 0.0 & 0.2 & 6.2 \\
\hline Philippines & 0.0 & 0.1 & 4.3 \\
\hline Singapore & 0.0 & 0.1 & 0.5 \\
\hline Thailand & 0.0 & 0.0 & 2.9 \\
\hline
\end{tabular}

Sources: The Bank of Korea, (current state of outward FDI), December 31, 1992. Quoted in Lee Kyung Chan, "South Korea-Malaysia Relations: A Study of Political Economy of Interdependence", p. 275

Table 10: Major Investment Projects by Korea, 1980-1992

\begin{tabular}{|l|l|l|}
\hline Name of Company & Products Approved for Manufacturing & $\begin{array}{c}\text { Capital } \\
\text { investment from }\end{array}$ \\
\hline Samsung Corning Co Ltd & $\begin{array}{l}\text { Polished glass panels \& glass funnels for } \\
\text { CPT (80\% Export) }\end{array}$ & RM 445.2 Million \\
\hline Samsung Electronic Devices(M) Sdn. Bhd & $\begin{array}{l}\text { Cathode ray tubes \& electron } \\
\text { guns }\end{array}$ & RM 391.1 Million \\
\hline Pohang Iron \& Steel Ltd Co. ( POSCO) & Cold rolled steel coil (50\% Export) & RM 601.9 Million \\
\hline Korean Iron \& Steel Co Ltd (KISWIRE) & Various steel wires & RM 92.6 Million \\
\hline Samsung Electronics video (M) Sdn Bhd & VCR (80\% Export) & 42.7 Million \\
\hline Samsung Electronics Sdn (M) Sdn Bhd & Microwave Iven (85\% Export) & \\
\hline
\end{tabular}

Source: Investment Brief on the Republic of Korea, Industrial Promotion Division, October, 1994, National Archives of Malaysia - Arkib Negara.

A similar investment trend can be found during Kim Young-Sam and Kim Dae-Jung periods. It is in the construction sector that the Korean presence was the most visible. In 1992, Malaysia was the second-largest overseas market for the operation of South Korean construction firms. Malaysia's LEP was timely as it opened up new opportunities for the then depressed South Korean construction industry. The Penang Bridge, Menara Maybank Building, and the PETRONAS twin towers were projects through which Korean newcomers penetrated into the Malaysian economy. 
South Korean involvement in high profile Malaysia's infrastructure projects is difficult to ignore. ${ }^{48}$ With economic linkages between the Malaysia and South Korea becoming firmer year by year, it is no wonder that a South Korean engineering corporation was given the job in 1985 to construct the Penang Bridge, Southeast Asia's lengthiest cable-stayed bridge, to link Peninsular Malaysia with the Penang Island. ${ }^{49}$ After a decade, in 1998, two construction companies of South Korea were involved in Malaysia's most admired building project, the PETRONAS Twin Towers. One company constructed one of the two towers and the other company connected the two towers by constructing the sky bridge.

As far as manufacturing is concerned, although investment from South Korea in this sector in Malaysia was not significant in the earlier years of the 1980s, the prospect became positive in 1988 when 11 projects involving a total capital investment of RM 41.8 million were approved, compared to previously only3 projects with a total capital investment of RM 188.9 million. This encouraging trend continued into 1989 when total projects approved reached 29 with a total capital investment of RM 188.9 million (Figure 7).

\section{Figure 7: South Korean Investment in Manufacturing Sector of Malaysia}

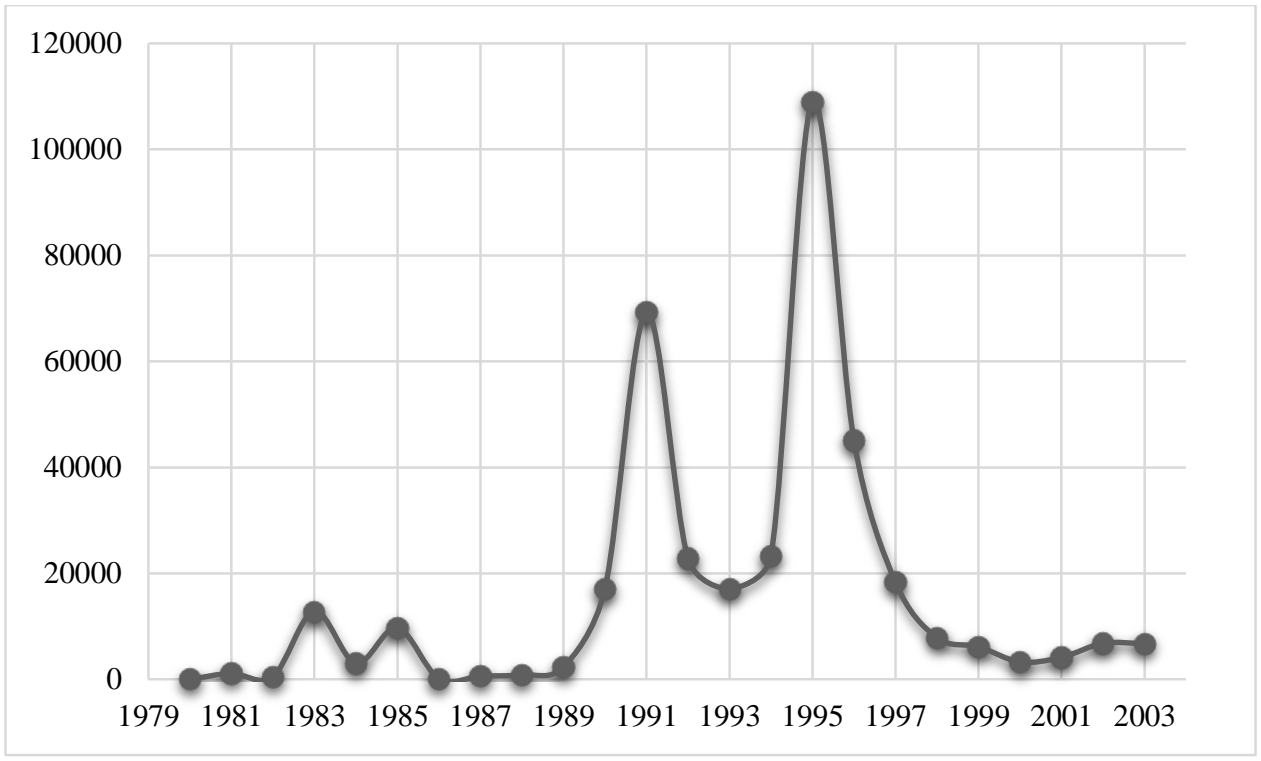

Source: EXIM Bank Korea, 1979-2003

During the periods of Chun and Roh, South Korean investments in Malaysia concentrated in the construction, manufacturing, and retail industries. Nevertheless, investment became more diversified as their bilateral relationship grew with time. As can be seen in Table 11, investment in the construction and manufacturing industries started to increase throughout the administrations of Chun Doo-Hwan until Kim Dae-Jung. During the first democratic government of Kim Young-Sam, South Korean investment in all of these industries increased more considerably that it had been in the previous regimes. However, compared with Kim Dae-Jung government, the difference is not as high in the construction, wholesale and retail as well as agricultural industries. During Kim Young-Sam's period, Malaysia-South Korea's economic relations saw an upward trend in the investment sector. One notable development in this period is the large investment in Information Technology (IT) and communication sectors, both of which 
were absent in the Chun Doo-Hwan and Roh Tae-Woo periods and very much negligible under Kim Dae-Jung.

Table 11: Leadership and Investment Growth

\begin{tabular}{|l|c|c|c|c|}
\hline $\begin{array}{l}\text { Investment in } \\
\text { Industries }\end{array}$ & $\begin{array}{c}\text { Chun Doo-Hwan } \\
\mathbf{1 9 8 0 - 1 9 8 8}\end{array}$ & $\begin{array}{c}\text { Roh Tae-Woo } \\
\mathbf{1 9 8 8 - 1 9 9 2}\end{array}$ & $\begin{array}{c}\text { Kim Young-Sam } \\
\mathbf{1 9 9 3 - 1 9 9 8}\end{array}$ & $\begin{array}{c}\text { Kim Dae-Jung } \\
\mathbf{1 9 9 8 - 2 0 0 3}\end{array}$ \\
\hline Construction & $1.22 \%$ & $1.48 \%$ & $50.07 \%$ & $47.22 \%$ \\
\hline Manufacturing & $7.19 \%$ & $28.96 \%$ & $56.87 \%$ & $6.98 \%$ \\
\hline Wholesale and Retail & $0.35 \%$ & $10.13 \%$ & $57.14 \%$ & $32.38 \%$ \\
\hline Mining & $1.36 \%$ & $0.83 \%$ & $10.02 \%$ & $87.80 \%$ \\
\hline Real Est. & $0.00 \%$ & $18.34 \%$ & $80.10 \%$ & $1.56 \%$ \\
\hline Agriculture & $0.00 \%$ & $70.73 \%$ & $12.36 \%$ & $16.92 \%$ \\
\hline IT & $0.00 \%$ & $0.00 \%$ & $96.14 \%$ & $3.86 \%$ \\
\hline Transportation & $0.00 \%$ & $0.00 \%$ & $90.30 \%$ & $9.70 \%$ \\
\hline
\end{tabular}

Source: Author's calculations.

Overall, since 1989, South Korean investments in Malaysia, primarily in manufacturing, increased so much so that in 1991 it exceeded Singapore investments. In 1992 with a share of 7.9\%, South Korea ranked the fifth largest investor for Malaysia. As indicated by one survey, 119 manufacturing operations, 12 construction firms and 14 South Korean trading companies operated in Malaysia in 1994. This increase in investment was particularly obvious during the tenure of Dr. Mahathir who encouraged more investments from Japan and South Korea. Investments in the early 1990s were concentrated around labour-intensive industries like wooden furniture, textile, and garments. However, this trend has now been substituted by investment in capital-intensive industries such as machinery and metal assembly. Investment of South Korean enterprises in Malaysia was fairly active over the subsequent years, and by July 1995, a total of 148 investment projects with an amount of US\$320 million (based on approval by the SouthKorean Bank) were carried out. ${ }^{50}$ This amount denotes $2.2 \%$ of South Korea's total overseas investment, while Malaysia the ninth largest investment beneficiary from South Korea. The availability of adequate economic infrastructures, simplification of administrative procedures and provision of additional incentives, all contributed to the expansion of investment by South Korean companies in Malaysia.

As a result, South Korea's contribution to the Malaysian economy cannot be overstated. Investments such as in Samsung Display Devices' extension of its color picture tube plant and Anam Semiconductor Technology's investment in semiconductor lead frame signified the rise of South Korean investment in technology-intensive companies (see Table 12). Due to continuous investment by South Korea in technology-intensive areas, technology transfer occurred along the way. 
Sejarah, No. 27, Bil. 1, 2018, hlm. 111-134.

Table 12: Major Technology Transfer

\begin{tabular}{|l|l|l|l|}
\hline \multicolumn{1}{|c|}{ Korean Firms } & \multicolumn{1}{|c|}{ Invested Area } & Investment in US\$ & \multicolumn{1}{c|}{ Progress } \\
\hline $\begin{array}{l}\text { Anam Semiconductor } \\
\text { Technology }\end{array}$ & Lead Frame (semiconductor part) & 16 million & $\begin{array}{l}\text { Produced } 6 \text { million units } \\
\text { per month in the first half } \\
\text { of } 1997\end{array}$ \\
\hline Samsung Display Device & Color Picture Tube & 304 million & $\begin{array}{l}\text { Addition of the } 5^{\text {th }} \text { and } 6^{\text {th }} \\
\text { assembly line, worth } \\
\text { US\$ } 150 \text { million began in }\end{array}$ \\
\hline
\end{tabular}

Source: Investment Projects with Technology Transfer from South Korea, National Archives, Arkib Negara, Malaysia, 2000

\section{Conclusion}

Under the leadership of Dr. Mahathir, the economic relations between Malaysia and South Korea improved substantially. Both countries increased their bilateral interaction in economic as well as in the political spheres but it was the former that stood out as the most profitable. South Korea increased its investment in Malaysia in various fields including manufacturing, technology transfer and construction. Due to the increased economic cooperation between Malaysia and South Korea, South Korea in Malaysia carried out mega projects notably the PETRONAS Twins Tower and the Penang Bridge construction. Similarly, Samsung Electronics increased its manufacturing operations in Malaysia. All these projects and investments contributed immensely to the economic growth of Malaysia. These investments projects not only created employment opportunities for Malaysians but also improved the Gross Domestic Product (GDP) of Malaysia. From 1970-2003, the manufacturing industry proportion in Malaysia's GDP increased from $13.76 \%$ to $29.93 \%$, and industry proportion also increased from $30.32 \%$ to $46.58 \%$. The greatest increase in this is seen to have taken place most evidently during Dr. Mahathir's era when Malaysia adopted a more liberal approach towards bilateral trade and investment. During Dr. Mahathir's era, Malaysian economic condition improved by leaps and bounds.Overall, unlike the 1960s and 1970s where ideological and political cooperation had dominated their bilateral agenda, the issue of economic cooperation replaced political agenda as the central theme of bilateral relations between Malaysia and South Korea during the 1980s. This was the leadership role both in Malaysia and South Korea that shaped the strength and direction of the bilateral relations. Maximizing South Korean President Chun's inclination towards the ASEAN countries in the 1980s, Dr. Mahathir quickly established a strong bilateral rapport with the East Asian country through the formulation of the LEP. Indeed, South Korea was one of the two main countries which were the cardinal focus of Mahathir's LEP. Its economic development was the benchmark for Malaysia's own. Ever since,the economic cooperation between Malaysia and South Korea constituted a major link between the Newly-Industrialized Economies (NIEs) ASEAN countries with the more industrialized countries. ${ }^{51}$ 


\section{Notes}

${ }^{1}$ See Stephen Woolcock and Nicholas Bayne, "Economic Diplomacy", in Andrew F. Cooper, Jorge Heine, Ramesh Thakur, eds., The Oxford Handbook of Modern Diplomacy, Oxford: Oxford University Press, 2013, pp. 385-401.

${ }^{2}$ K. Mauzy and R.S. Milne, "The Mahathir Administration: Discipline through Islam", Pacific Affairs, 56:4, 1983/1984, pp. 617-648.

3 Lee Poh Ping and Hong Seok Jeong, "ASEAN, South Korea and the Asia-Pacific Region", in Daljit Singh and Reza Y. Siregar, eds., ASEAN and Korea: Emerging Issues in Trade and Investment Relations, Singapore: Institute of Southeast Asian Studies (ISEAS), 1995, p. 22.

4 Kit G. Machado, "Malaysian Cultural Relations with Japan and South Korea in the 1980s", Asian Survey, 27:6, 1987, p. 638

${ }^{5}$ Lee Poh Ping and Hong Seok Jeong, "ASEAN and Korea: Emerging Issues in Trade and Investment Relations", p. 22

${ }^{6}$ The trade negotiation between the Federation of Malaya and the Republic of Korea was initiated on September 81962 at a ceremony held in the Selangor State Assembly Chamber, Kuala Lumpur. The signing of trade deal was held in South Korea. The initialization was carried out in the presence of the delegates from both countries. Among

${ }^{7}$ Malaysian Investment Development Authority (MIDA).

http://www.matrade.gov.my/cms/content.jsp?id=com.tms.cms.bookmark.Bookmark_hide_KoreaFTA.

Accessed 6 July 2018.

${ }^{8}$ See Juzhong Zhuang, David Edwards and Ma. Virginita A. Capulong, D. Edwards, \& Capulong, Corporate Governance \& Finance in East Asia: A Study of Indonesia, Republic of Korea, Malaysia, Philippines and Thailand, Manila: Asian Development Bank, 2001.

${ }^{9}$ This was to be expected as both countries were still undergoing their respective formative development. Korea in particular, was still facing internal political instabilities and the repercussions of the Korean War. Following the Korean War, South Korea was one of the poorest countries in the world for over a decade. In 1960 its Gross Domestic Product (GDP) per capita was \$79 - lower than that of some sub-Saharan countries. The country's GDP was a mere \$1.5 billion and per capita GDP was only \$70 in 1954 . Following the formulation and implementation of the five-year economic plan, South Korea underwent rapid industrialization to develop the economy. See Karin Wessel, "Basic Features of Economic and Regional Development in South Korea", in Regional Development and Decentralization Policy in South Korea, edited by Ludwig Schätzl, Karin Wessel and Yong-Woo Lee, Singapore: Institute of Southeast Asian Studies (ISEAS), 1997, pp. 34-176.

${ }^{10}$ Tat Yan Kong, "Democratisation and its Aftermath: Transition and Continuity in South Korea", in Dae Hwan Kim and Tat Tan Kong, eds., The Korean Peninsula in Transition, New York: St. Martin's Press, Inc., 1997, p. 98.

${ }^{11}$ Hojin Kang, "The Development Experience of South Korea - The Role of Public Policy", in Industrial Policy, Innovation and Economic Growth: The Experience of Japan and the Asian NIEs, Singapore: Singapore University Press, 2001, p. 354.

${ }^{12}$ Uqbah Iqbal, "History of Look-To-The-East Idea: South Korea Interests in the Socio-Economic Development of Malaysia, International Journal of Economics and Financial Research, 13:11, 2017, p. 251.

${ }^{13}$ The Saemaul Undong movement was a community-driven development program of the Republic of Korea in the 1970s. The movement contributed to improved community well-being in rural communities through agricultural production, household income, village life, communal empowerment and regeneration, and women's participation. 
${ }^{14}$ Malaysia signed the Double Taxation Agreement with South Korea on 20th April 1982 and in 1988 for the purpose of avoiding incidences of double taxation on international incomes such as business profits, dividends, interests and royalties, which were derived in one country and remitted to another country.

15 The meetings named "Korea-Malaysia Official Level Meeting on the Technical Cooperation with regard to the Look East Policy Program of Malaysia" took place in Seoul, Korea on the following dates: (1) 7-8 July 1983; (2) 18-19 July 1985; (3) 27-28 November 1986; (4) 7-8 April 1988; (5) 20-21 January 1992; and (6) 5-6 July 1993.

${ }^{16}$ Jason P. Abott, Developmentalism and Dependency in Southeast Asia: The case of the Automotive Industry, London: RoutledgeCurzon, 2003, p. 85.

${ }^{17}$ Boo Teik Khong, Paradoxes of Mahathirism: An Intellectual Biography of Mahathir Mohamad, Oxford: Oxford University Press, 1995, p.68.

${ }^{18}$ Speech by Tun Mahathir in Seoul, Korea, August, 09, 1983. See Murugesu Pathmanathan and David Lazarus, Winds of Change: The Mahathir Impact on Malaysia's Foreign Policy, Kuala Lumpur: Eastview Publications, 1984, p.229.

${ }^{19}$ Ibid.

${ }^{20}$ Kwan S. Kim, "The Korean Miracle (1962-1980) Revisited: Myths and Realities in Strategy and Development" Working Paper \#166, Kellogg Institute: The Helen Kellogg Institute for International Studies, November 1991, p. 4.

${ }^{21}$ Johan Saravanamuttu, "Malaysia's Foreign Policy in the Mahathir Period, 1981-1995: An Iconoclast Come to Rule," Asian Journal of Political Science 4, no. 1 (1996).

${ }^{22}$ Liow, Joseph. "Personality, Exigencies and Contingencies: Determinants of Malaysia's Foreign Policy in the Mahathir Administration." Ho Khai Leong and James Chin. Mahathir's Administration: Performance and Crisis in Governance. Singapore: Times Books (2001): 120-160.

${ }^{23}$ John Bresnan, From Dominoes to Dynamos: The Transformation of Southeast Asia, New York: Council on Foreign Relations Press, New York, 1994, pp. 35-36.

${ }^{24}$ S. Kuruvilla and C.S. Venkataratnam, "Economic Development and Industrial Relations: The Case of South and Southeast Asia", Industrial Relations Journal, 27: 1, 1996, pp. 9-23

${ }^{25}$ C.H. Cho, "Korean Wave in Malaysia and Changes of the Korea-Malaysia Relations", Malaysian Journal of Media Studies, 12: 1, 2010, pp. 1-14.

26 Lee Kyung Chan, "South Korea-Malaysia Relations: A Study of Political Economy of Interdependence", Department of Southeast Asian Studies, Master Thesis, University of Malaya, 1995, p. 228.

27 Lee Kyung Chan, "South Korea-Malaysia Relations: A Study of Political Economy of Interdependence", p. 229.

${ }^{28}$ Ibid., p. 269.

${ }^{29}$ Ibid.

${ }^{30}$ Lee Poh Ping and Hong Seok Jeong, "ASEAN, South Korea and the Asia-Pacific Region”, pp. 17-18.

${ }^{31}$ Roh made a speech on June 29 promising a wide program of reforms. Chief among them were a new, more democratic constitution and popular election of the president. In the election, the two leading opposition figures, Kim Young-sam and Kim Dae-jung (both of whom later became presidents), were unable to overcome their differences and split the vote, in spite of the first female presidential candidate withdrawing from the race to support Kim Young-sam against Roh. This enabled Roh to win by a narrow margin and become the country's first cleanly elected president on December 16, 1987 and was inaugurated as President on February 25, 1988.

${ }^{32}$ See Edward M. Graham, Reforming Korea's Industrial Conglomerates, Washington D.C: Peterson Institute, 2003.

${ }^{33}$ The average growth rates are calculated based on the data retrieved from Malaysian Investment Development Authority (MIDA) from 1980 to 1992. 
${ }^{34}$ Higher Level Visits by South Korean Officials to Malaysia, 1961-1991, Ministry of Foreign Affairs, Malaysia.

35 "Mahathir, The Past and The Present". http://www.mahathir.com/malaysia/speeches/1990/1990-0912.php. Accessed 7 July 2018.

${ }^{36}$ Kakali Mukhopadhyay and Paul J. Thomassin, Economic and Environmental Impact of Free Trade in East and South East Asia, London: Springer, 2010, pp. 63-64.

${ }^{37}$ In September 1990, South Korean and Malaysia signed an agreement by which Malaysia Liquefied Natural Gas Sdn. Bhd. (MLNG) agreed to supply South Korea two million tons of LNG worth RM 850 million annually over a 20-year period starting from 1995. MLNG, a subsidiary of PETRONAS, also agreed to sell a total of 700,000 tons of liquefied natural gas to South Korea between 1992 and 1994 under a series of short-term contracts.

${ }^{38}$ The statistics are taken from the World Integrated Trade Solution database on bilateral trade by product between Malaysia and South Korea.

${ }^{39}$ See Lee Poh Ping and Hong Seok Jeong, "ASEAN, South Korea and the Asia-Pacific Region”, in Daljit Singh and Reza Y. Siregar, eds., ASEAN and Korea: Emerging Issues in Trade and Investment Relations, Singapore: Insttute of Southeast Asian Studies (ISEAS), 1995, pp. 21-32.

${ }^{40}$ See "MATRADE Matches Malaysian Companies with South Korean Buyers at Its INSP Malaysia External Trade Development Corporation". http://www.matrade.gov.my/en/archive/3540-matradematches-malaysian-companies-with-south-korean-buyers-at-its-insp. Accessed 7 July 2018.

41 "MATRADE Matches Malaysian Companies with South Korean Buyers at Its INSP Malaysia External Trade Development Corporation". For comparison with South Korean's export trade with China, see Eun Mee Kim and Jai S. Mah, "Patterns of South Korea's Foreign Direct Investment into China", Asian Survey, 46:6, 2006, pp. 881-897.

${ }^{42}$ Researchers' interview with Tun Mahathir conducted on August, 29, 2017.

${ }^{43}$ Due to the second oil shock in 1979 , inflation was high and was threatening the economy. The policy efforts by the previous government to reduce inflation were not successful due to the intense investment in the heavy chemical industry (HCI). The economic structure was based on big business conglomerates (chaebol), which was causing problems in the economic structural as well as an unequal distribution of wealth. To make matters worse, the international economic environment was not friendly to Korean exports either. The second oil shock brought on an international recession, which gave rise to protectionism in many countries. To confront these problems, the Chun administration adopted aggressive policy measures to continue to develop the economy in order to compensate for the lack of political legitimacy.

${ }^{44}$ Malaysia and South Korea signed an Investment Guarantee Agreement on 4th February 1988 to create favorable conditions for the promotion and reciprocal protection of Investments and interests made by nationals of both the signatories.

${ }^{45}$ Murugesu Pathmanathan and David Lazarus, Winds of Change, the Mahathir Impact on Malaysia's Foreign Policy, p. 47.

${ }^{46}$ K.S. Jomo, "Privatization in Malaysia: For What and For Whom", in Thomas Clarke and Christos Pitelis, eds., The Political Economy of Privatization, London: Routledge, 1993, p. 255.

${ }^{47}$ Investment Brief on the Republic of Korea, Industrial Promotion Division, October, 1994, National Archives of Malaysia - Arkib Negara. During 1987-1990, Malaysia's imports doubled. During this period, Korean companies' high-wage high interest rates worsened due to the rise in raw material prices, and the production facilities have been transferred to Southeast Asian countries, such as Malaysia, where wages and raw materials are abundant. The fact that these investment companies started to import the equipment, parts and materials for the plant construction from Korea was a major factor in Malaysia's increase in imports.

${ }^{48}$ On 22 November 1993, Kuala Lumpur City Center Bhd (KLLC) awarded contracts worth RM 945 million for the construction of the PETRONAS Twin Towers to two foreign led consortiums, marking 
another milestone in the development of the multi billion Ringgit project. The towers with pinnacles reaching 450 meters high, is said to be tallest building in the world. Samsung the biggest South Korean chaebol or conglomerate is executing as of November 1993, five construction projects in Malaysia except the PETRONAS Twin Towers project: the Malaysian National Insurance head office building valued at RM 146 million, the Lusaka office building at RM 82 million, Tuanku Jaafar Golf and Country Resort worth RM 29 million and a Tenaga Nasional Bhd. substation at RM 12 million (The Star, 23 November 1993). Samsung is also the biggest Korean manufacturing investor in Malaysia.

${ }^{49}$ Ooi Keat Gin, The A to $Z$ of Malaysia,Volume 212 of The A to Z Guide Series, Lanham: Scarecrow Press, Inc., 2009, p. 247.

${ }^{50}$ In strongly urging Korean businessmen to seek investment opportunities in Malaysia, Dr. Mahathir stressed that "Malaysia has hot a lot to offer in terms of raw materials particularly wood... more possibly for furniture making and also other raw materials that may be use to [Koreans]". New Straits Times, 15 August 1983.

${ }^{51}$ There were several other regional organizations evolved in the 1960s such as the Asian Development Bank (ADB), the Asia productivity Organization (APO), the Asian Institute for Economic Development Council (AIDC), etc. However in most cases, these were either functional organizations or had direct links with countries out of the region or with the U.N. 